Funding This study was supported by a Pfizer Neuroscience Research Grant.

\section{H05 GENE EXPRESSION PROFILE IN FIBROBLASTS OF HUNTINGTON'S DISEASE PATIENTS AND CONTROLS}

doi:10.1136/jnnp.2010.222653.5

${ }^{1} E$ Marchina, ${ }^{1} \mathrm{~A}$ Bozzato, 'S Ferraboli, ${ }^{2} \mathrm{C}$ Agosti, ${ }^{2} \mathrm{~L}$ Rozzini, ${ }^{1} \mathrm{G}$ Borsani, ${ }^{1} \mathrm{~S}$ Barlati, ${ }^{2}$ A Padovani. ${ }^{1}$ Biology and Genetics Unit, Department of Biomedical Sciences and Biotechnologies, University of Brescia, Brescia, Italy; ${ }^{2}$ Neurology Unit, Department of Medical and Surgical Sciences, University of Brescia, Brescia, Italy

Huntington's disease (HD), MIM 143100, is a dominantly inherited progressive neurodegenerative disorder characterised by motor, behavioural and cognitive dysfunction, caused by an expanded CAG repeat region in exon 1 of the HTT gene. This mutation results in the presence of an abnormally long polyglutamine tract in the encoded protein, huntingtin. Research into this disorder has conventionally focused on neurological symptoms and brain pathology, particularly neurodegeneration in the basal ganglia and cerebral cortex. Mutant huntingtin is, however, ubiquitously expressed throughout the body. Contrary to earlier thinking, HD is also associated with abnormalities in peripheral tissues. Due to obvious problems in obtaining brain tissue, these peripheral tissues can be studied to elucidate pathogenetic mechanism (still not well understood) of the disease as well as identifying disease biomarkers. Peripheral tissue dermal fibroblasts, which have the same ectodermal origin as CNS cells, may represent an alternative source for biological studies. Furthermore, contrary to peripheral blood cells, this cell type is not directly exposed to drugs. We performed gene expression profile analysis of human fibroblasts obtained from HD patients and healthy controls matched by age and sex. The study was performed using the whole genome Affymetrix HG U133 plus 2.0 arrays. Preliminary data obtained indicate that 451 genes are upregulated twofold or greater in patients compared with controls while 17 are downregulated. This study allowed us to evidence the modulation at the transcriptional level of a discrete number of genes relevant in biological processes which are altered in the disease-processes such as transcription and its regulation, apoptosis, regulation of actin cytoskeleton, inositol phosphate metabolism and vesicle mediated transport. We plan to extend this type of analysis to a larger number of cases and controls and to confirm the differential expression of interesting genes both at the RNA and protein levels. The data generated by this study could provide novel clues on the Huntington pathogenesis and lead to the identification of a set of mRNAs that appear to be useful as biomarkers of the disease.

\section{H06 CROSS SECTIONAL AND LONGITUDINAL 3T MAGNETIC RESONANCE SPECTROSCOPY IN A TRACK-HD COHORT OF INDIVIDUALS WITH PREMANIFEST AND EARLY HUNTINGTON'S DISEASE}

doi:10.1136/jnnp.2010.222653.6

\begin{abstract}
${ }^{1} \mathrm{~A}$ Sturrock, ${ }^{2} \mathrm{C}$ Laule, ${ }^{1} \mathrm{~J}$ Decolongon, ${ }^{1} \mathrm{R}$ dar Santos, ${ }^{1} \mathrm{~A} \mathrm{~J}$ Coleman, ${ }^{1} \mathrm{~S}$ Creighton, ${ }^{3} \mathrm{~N}$ Bechtel, ${ }^{3} \mathrm{R}$ Reilmann, ${ }^{1} \mathrm{M}$ R Hayden, ${ }^{4} \mathrm{~S} J$ Tabrizi, ${ }^{2} \mathrm{~A}$ L Mackay, ${ }^{1} \mathrm{~B}$ R Leavitt. ${ }^{1}$ Department of Medical Genetics, University of British Columbia (UBC), Vancouver, British Columbia, Canada; ${ }^{2}$ UBC MRI Research Centre, University of British Columbia, Vancouver, British Columbia, Canada; ${ }^{3}$ Department of Neurology, University of Münster, Münster, Germany; ${ }^{4}$ UCL Institute of Neurology, University College London, London, UK
\end{abstract}

Background A potential biomarker role for magnetic resonance spectroscopy (MRS) in Huntington's disease (HD) is unclear due to conflicting reports in the literature.
Aim To investigate MRS as an HD biomarker through cross sectional and longitudinal examinations in a TRACK-HD study cohort.

Methods Cross sectional MRS of the left putamen (at $3 \mathrm{~T}$ field strength) was performed in the University of British Columbia TRACK-HD study cohort. 84 individuals (30 controls (C), 25 preHD (P), 29 early HD (E)) were scanned at baseline. 78 individuals (29 (C), $26(\mathrm{P})$ and $23(\mathrm{E}))$ underwent repeat MRS examination at 1 year. Metabolites of interest were total $\mathrm{N}$-acetyl aspartate (tNAA) and myo-inositol (MI); markers of neuronal health and gliosis.

Results Baseline tNAA concentrations in early HD were lower than in controls (mean (SD) $8.6(0.7) \mathrm{mM}(\mathrm{C})$ vs 7.3 (1.2) $\mathrm{mM}$ (E); $\mathrm{p}<0.001)$. MI was higher in early HD compared with controls $(6.0$ (2.6) $\mathrm{mM}$ (E) vs 4.3 (1.4) $\mathrm{mM} \mathrm{(C);} \mathrm{p<0.005).} \mathrm{After} 1$ year, MI concentrations remained 40\% higher in early $\mathrm{HD}(6.0(2.7) \mathrm{mM}(\mathrm{E})$ vs 4.2 (1.1) $\mathrm{mM}(\mathrm{C}) ; \mathrm{p}<0.01)$. tNAA was still lower in early HD $(\mathrm{p}<0.001)$ but also in pre-HD $(\mathrm{p}<0.05)$ than controls $(7.4(0.9) \mathrm{mM}$ (E) vs $8.2(0.8) \mathrm{mM}(\mathrm{P})$ vs $8.7(0.6) \mathrm{mM}(\mathrm{C})$ ). Neither tNAA nor MI exhibited longitudinal change in any group. A novel observation was that of $30 \%$ increases in spectral linewidth in early $\mathrm{HD}$ at both time points $(\mathrm{p}<0.01)$.

Conclusions Our data support patterns of higher MI levels and lower tNAA in early HD. The pattern of lower tNAA may begin in premanifest HD. The lack of longitudinal metabolite change is not unusual over such a short duration of follow-up. We also identified for the first time, consistent increases in MRS spectral linewidth in early $\mathrm{HD}$

\section{H07 PRIMARY SKIN FIBROBLAST CULTURES IN HUNTINGTON'S DISEASE RESEARCH}

doi:10.1136/jnnp.2010.222653.7

L Hasholt, S B Nielsen, N H Skotte, J E Nielsen, A Nørremølle. Section of Neurogenetics, Department of Cellular and Molecular Medicine, University of Copenhagen, The Panum Institute, Copenhagen, Denmark

Background Cultured skin fibroblasts from HD patients seem to be an attractive model for in vitro studies of molecular pathology in $\mathrm{HD}$, and in the hunt for HD biomarkers, as sampling is minimally invasive and the effect of the mutation can be studied in the correct genetic background.

Aims Here we discuss results gathered from the literature together with some of our own unpublished results on $\mathrm{HD}$ patient fibroblasts.

Outcome Although HD primary fibroblast cultures have been established and studied for a long time, results revealing characteristic phenotypic traits of this cell type are sparse. Many investigations have focused on growth characteristics but no conclusion could be drawn just as studies of cellular morphology so far have yielded somewhat confounding results. There have been multiple explanations suggested, including variations in growth characteristics of individual cell lines, which are also known from normal fibroblast cultures, and differences in culture conditions like the use of different culture media, concentration of serum, addition of antibiotics, surface of culture disc, etc, conditions which make it difficult to compare results obtained from different experimental set-ups. Recently, examples of functional deficits have been found in HD fibroblasts including vesicular trafficking, lipid metabolism and proteasome inhibition as well as growth factor and enzyme activity changes. Future investigations are needed to reveal the pathways involved and to show if they relate to changes in CNS.

Conclusion Our considerations are useful for planning collection of skin biopsies and multicentre studies on cultured fibroblasts. 

Huntington's disease patients and controls

\author{
E Marchina, A Bozzato, S Ferraboli, et al.
}

J Neurol Neurosurg Psychiatry 2010 81: A35

doi: 10.1136/jnnp.2010.222653.5

Updated information and services can be found at:

http://jnnp.bmj.com/content/81/Suppl_1/A35.1

\begin{tabular}{cc}
\hline These include: \\
$\begin{array}{c}\text { Email alerting } \\
\text { service }\end{array}$ & $\begin{array}{c}\text { Receive free email alerts when new articles cite this article. Sign up in } \\
\text { the box at the top right corner of the online article. }\end{array}$ \\
\hline $\begin{array}{c}\text { Topic } \\
\text { Collections }\end{array}$ & $\begin{array}{c}\text { Articles on similar topics can be found in the following collections } \\
\text { Movement disorders (other than Parkinsons) (598 articles) } \\
\text { Drugs: CNS (not psychiatric) (1349 articles) } \\
\text { Memory disorders (psychiatry) (1000 articles) } \\
\text { Stroke (1107 articles) }\end{array}$ \\
\hline
\end{tabular}

Notes

To request permissions go to:

http://group.bmj.com/group/rights-licensing/permissions

To order reprints go to:

http://journals.bmj.com/cgi/reprintform

To subscribe to BMJ go to:

http://group.bmj.com/subscribe/ 